\title{
Expression of the Oenococcus oeni trxA gene is induced by hydrogen peroxide and heat shock
}

\author{
Michel-Philippe Jobin, Dominique Garmyn, Charles Diviès \\ and Jean Guzzo
}

Author for correspondence: Jean Guzzo. Tel: +33 380396675. Fax: +33380396640. e-mail: jguzzo@u-bourgogne.fr

Laboratoire de

Microbiologie, U. A. INRA, ENSBANA, 1 Esplanade Erasme, 21000 Dijon, France

\begin{abstract}
Sequencing of the DNA region located upstream of the $\alpha$-acetolactate synthase and decarboxylase (alsS-alsD) cluster of Oenococcus oeni allowed identification of an ORF, named trxA. This encodes a protein of 104 amino acids very similar to known thioredoxins. The protein encoded by the cloned fragment was able to complement Escherichia coli strains lacking a functional thioredoxin. Considering the results of protein sequence comparisons and complementation experiments, it was concluded that the trx $A$ gene encodes a functional thioredoxin. Studies of trxA expression showed that the abundance of trxA mRNA was similar during all growth stages. A significant increase in trxA mRNA levels was observed in the presence of hydrogen peroxide in the medium or after heat shock. A single transcriptional start site was determined with total RNA isolated from cells subjected or not subjected to oxidative stress or heat shock. In each case the same promoter region was identified and shown to have a high similarity to the consensus promoter sequence of Grampositive bacteria, as well as to that of $E$. coli and the previously mapped promoters from 0 . oeni.
\end{abstract}

Keywords: Oenococcus oeni, thioredoxin, oxidative stress, heat shock

\section{INTRODUCTION}

Thioredoxins have been isolated and characterized from many micro-organisms, plants and animals (Holmgren, 1985). Such proteins are involved in a wide variety of biochemical processes in living cells. Reduced thioredoxin serves as an efficient hydrogen donor for many reductase enzymes and protein disulfide isomerases (Holmgren, 1989). The active site of thioredoxin (TrpCys-Gly-Pro-Cys) is highly conserved and contains two redox-active cysteine residues, which form either a disulfide (oxidized form) or a dithiol (reduced form). The $S-S$ bond of oxidized thioredoxin is reduced by NADPH and a specific enzyme called thioredoxin reductase (Moore et al., 1964).

Thioredoxin appears to be an essential protein for many organisms, such as Bacillus subtilis (Scharf et al., 1998), Synechocystis (Navarro \& Florencio, 1996) and Rhodobacter sphaeroides (Pasternak et al., 1997), in contrast to

The GenBank accession number for the sequence reported in this paper is XT93091.
Escherichia coli (Holmgren et al., 1978). A variety of stresses, including heat, salt stress or ethanol treatment, strongly enhance the synthesis of thioredoxin in $B$. subtilis (Scharf et al., 1998). In this species, a double control of stress induction at two different promoters has been demonstrated: the first promoter is $\sigma^{\mathrm{B}}$. dependant, whilst the second is presumably $\sigma^{\mathrm{A}}$-dependant and might require activation by some other unknown mechanism.

Oenococcus oeni is a lactic acid bacterium which is able to grow in wine and to perform the malolactic fermentation (Dicks et al., 1995; Kunkee, 1967; Labarre et al., 1996a). No information is available on thioredoxin synthesis and activity in this heterofermentative bacterium. In the course of our investigations on the stress response of $\mathrm{O}$. oeni, we previously studied an $18 \mathrm{kDa}$ small heat-shock protein (Lo18), highly induced by multiple stresses such as heat shock, acid shock, the presence of ethanol or sulfite, and in stationary phase (Guzzo et al., 1997, 1998). The hsp18 gene encoding this protein was cloned and characterized (Jobin et al., 1997). After purification of the protein, it was shown that Lo18 could form oligomers and prevent citrate 
synthase from thermal aggregation (F. Delmas, personal communication).

We report here the nucleotide sequence of a chromosomal DNA fragment encoding the thioredoxin of $O$. oeni. The size of the transcript and the transcriptional start site were determined and the expression of the gene in response to oxidative and heat stresses was investigated.

\section{METHODS}

Bacterial strains, plasmids and media. The strains and plasmids used in this study are listed in Table 1. E. coli strains were grown in Luria-Bertani (LB) broth or LB agar at $37^{\circ} \mathrm{C}$. In the selective medium the antibiotic erythromycin was used at a concentration of $200 \mu \mathrm{g} \mathrm{m}^{-1}$. O. oeni strain Lo84.13 was grown at $30^{\circ} \mathrm{C}$ in FT80 medium (pH 5.3) (Cavin et al., 1989), modified by adding meat extract $\left(5 \mathrm{~g} \mathrm{l}^{-1}\right)$ instead of Casamino acids.

DNA manipulations, sequencing and analysis. Molecular techniques were carried out using standard methods (Sambrook et al., 1989). Double-stranded plasmid DNA was purified with a Qiagen plasmid kit and sequenced using the dideoxy chain-termination method (Sanger et al., 1977). Computer analyses of nucleotide and amino acid sequences were carried out with the BLAST (Altschul et al., 1990) and CLUSTAL w programs (Higgins et al., 1994).

Isolation of total RNA and Northern blot analysis. O. oeni total RNA was purified as previously described (Labarre $e$ t al., 1996b) from control cells (grown at $30^{\circ} \mathrm{C}$ ), or cultivated in the

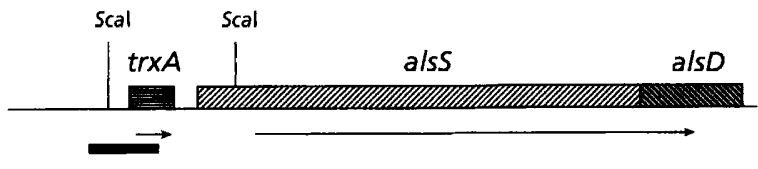

Fig. 1. 0 . oeni trxA-alsSD cluster. The positions of $\operatorname{trx} A$, alsS and $a / s D$ are indicated by boxes. The direction of transcription is indicated by arrows. Scal restriction sites are shown. The probe used for Northern blotting is indicated by the bold line below the map.

presence of hydrogen peroxide $\left(10 \mathrm{mg} \mathrm{l}^{-1}\right)$, or after addition of hydrogen peroxide $\left(8-20 \mathrm{mg} \mathrm{l}^{-1}\right)$ for 30 or $60 \mathrm{~min}$, or submitted to heat shock for 5-30 min. RNA $(30 \mu \mathrm{g})$ was separated in a $1.2 \%(\mathrm{w} / \mathrm{v})$ agarose $/ 6.6 \%(\mathrm{v} / \mathrm{v})$ formaldehyde gel and then transferred to Hybond- $\mathrm{N}+$ membranes (Amersham). The $\operatorname{tr} x A$ probe (Fig. 1) was radiolabelled with $\left[\alpha-{ }^{32} \mathrm{P}\right] \mathrm{dATP}$, using a Random Primer DNA Labelling System (Gibco-BRL). All the Northern blot analyses were repeated at least twice.

Primer extension analysis. Oligonucleotides (TRX1, 5'-CCG GAT TTG GTT GCT TCC TC-3'; TRX2, 5'-TCA GTC ACA GTC ACG CCG GA-3' ; and TRX3, 5'-TTG CCG AAT TTA ACC CTC GA-3') were used to map the $5^{\prime}$ terminus of $\operatorname{tr} x A$ mRNA in O. oeni. Total RNA $(5 \mu \mathrm{g})$ was mixed with 2 pmol of each primer. After a 5 min denaturation step at $100^{\circ} \mathrm{C}$, the mixture was cooled in ice for annealing. Reverse transcription was carried out as recommended by the manufacturer with the Superscript II RNase $\mathrm{H}^{-}$Reverse Transcriptase (Gibco-BRL). Analysis of the extension products was performed as previously described (Jobin et al., 1997).

Table 1. Bacterial strains and plasmids used in this study

\begin{tabular}{|c|c|c|}
\hline $\begin{array}{l}\text { Strain or } \\
\text { plasmid }\end{array}$ & Genotype or phenotype & Source or reference \\
\hline \multicolumn{3}{|l|}{ Strains } \\
\hline \multicolumn{3}{|l|}{ O. oeni } \\
\hline Lo84.13 & $\mathrm{MLE}^{+}$ & $\begin{array}{l}\text { Oenological Institute } \\
\text { of Bordeaux }\end{array}$ \\
\hline \multicolumn{3}{|l|}{ E. coli } \\
\hline TG1 & $\begin{array}{l}\text { supE hsd } \Delta 5 \text { thi } \Delta\left(\text { lac-proAB) } \mathrm{F}^{\prime}(\text { traD } 36\right. \\
\left.\text { pro } A^{+} B^{+} \text {lacl }^{\mathrm{q}} \text { lacZ } \Delta \mathrm{M} 15\right)\end{array}$ & Gibson (1984) \\
\hline AR1062 & $\begin{array}{l}\mathrm{F}^{-} \text {thr leu ara azi fhuA lacY tsx minA gal } \\
\text { rspL xyl mtl thi hsdR }\end{array}$ & D'Enfert et al. (1987) \\
\hline $\mathrm{BH} 2012$ & $\begin{array}{l}\mathrm{F}^{-} \text {araD139 ? galU galK hsdR rpsL metE46 } \\
\text { argH1 trxA2 ilvC::Tn5 }\end{array}$ & Lim et al. (1985) \\
\hline A.312 & $m e t E:: \operatorname{Tn} 10$ & Russel \& Model (1986) \\
\hline A313 & $\operatorname{tr} x A:: k a n$ metE::Tn10 & Russel \& Model (1986) \\
\hline \multicolumn{3}{|l|}{ Plasmids } \\
\hline pGID023 & $\begin{array}{l}\text { Shuttle vector for E. coli and L. plantarum, } \\
\text { derivative of pJDC9 containing pE194 } \\
\text { replication functions; } \mathrm{Em}^{\mathrm{R}}\end{array}$ & Hols et al. (1994) \\
\hline pGID600 & $\begin{array}{l}\text { pJDC9 containing a } 7 \mathrm{kbp} \text { Sau3A fragment } \\
\text { from O oeni DNA }\end{array}$ & Garmyn et al. (1996) \\
\hline pGID608 & $\begin{array}{l}\text { pGID023 containing a } 863 \text { bp Scal fragment } \\
\text { from pGID } 600\end{array}$ & This study \\
\hline
\end{tabular}




\section{RESULTS}

\section{Nucleotide sequence of trxA}

In a previous publication, we reported the isolation of a recombinant clone (pGID600) carrying the O. oeni alsSD cluster (Fig. 1) and the corresponding nucleotide sequence (Garmyn et al., 1996). We found an ORF in the same orientation as alsSD that terminated $115 \mathrm{bp}$ upstream of alsSD. We have now determined the nucleotide sequence upstream of this region by primerwalking using pGID600 as a template. An ORF of 104 codons is preceded by a putative ribosome-binding site (AAGGAGG) complementary to the sequence $3^{\prime}$ UUUCCUCCA (complementary bases underlined) at the 3' end of Leuconostoc mesenteroides 16S rRNA (Yang \& Woese, 1989). L. mesenteroides was taken as reference because the $3^{\prime}$ end of O. oeni $16 \mathrm{~S}$ rRNA has not been determined, and it is known that the sequence is conserved at the $3^{\prime}$ ends of different Gram-positive bacteria (Chassy \& Murphy, 1993). Furthermore, the genus Leuconostoc is closely related to Oenococcus (Dicks et al., 1995). Inspection of the 3' noncoding sequence showed an inverted repeat sequence that could form a stem-and-loop structure in mRNA with a calculated $\Delta G_{\mathrm{f}}$ of $-68 \mathrm{~kJ} \mathrm{~mol}^{-1}$. The deduced primary structure of the encoded TrxA is composed of 104 amino acids, with a predicted molecular mass of $11.5 \mathrm{kDa}$. The $O$. oeni TrxA exhibits sequence similarity to other bacterial TrxA (Fig. 2), with a particularity high sequence identity (48\%) to B. subtilis (Chen et al., 1989). The primary structure of $O$. oeni thioredoxin revealed the presence of a typical active centre. However, the sequence between the two vicinal Cys residues was different from that found in most thioredoxins, with the Gly residue replaced by a Thr residue.

\section{Expression in $E$. coli of the $O$. oeni trxA gene}

The predicted amino acid sequence provided strong evidence that the cloned DNA contained the trxA gene encoding the thioredoxin of $O$. oeni. To identify the $\operatorname{trx} A$ gene product, we used an E. coli minicell system which allowed specific labelling of plasmid-encoded proteins (D'Enfert et al., 1987). The 863 bp Scal DNA fragment of pGID600 (Fig. 1) was subcloned in pGID023. Minicells were prepared from E. coli AR 1062, which was transformed with plasmid pGID023 and pGID608. Proteins were labelled with $\left.\mathrm{L}-{ }^{[35} \mathrm{S}\right]$ methionine and analysed by SDS-PAGE (Labarre et al., 1996a). Minicells carrying pGID608 expressed a protein that had a molecular mass of almost $12 \mathrm{kDa}$ (data not shown). This apparent molecular mass is consistent with the calculated value deduced from the nucleotide sequence.

An in vivo assay for thioredoxin function was used to test whether the O. oeni $\mathrm{TrxA}$ protein can substitute for E. coli thioredoxin. E. coli contains the enzyme methionine sulfoxide reductase, which uses thioredoxin as a source of reducing power and thereby enables methionine-requiring strains to utilize methionine sulfoxide for growth (Russel \& Model, 1986). Two different mutant strains, BH2012 and A313, with phenotype

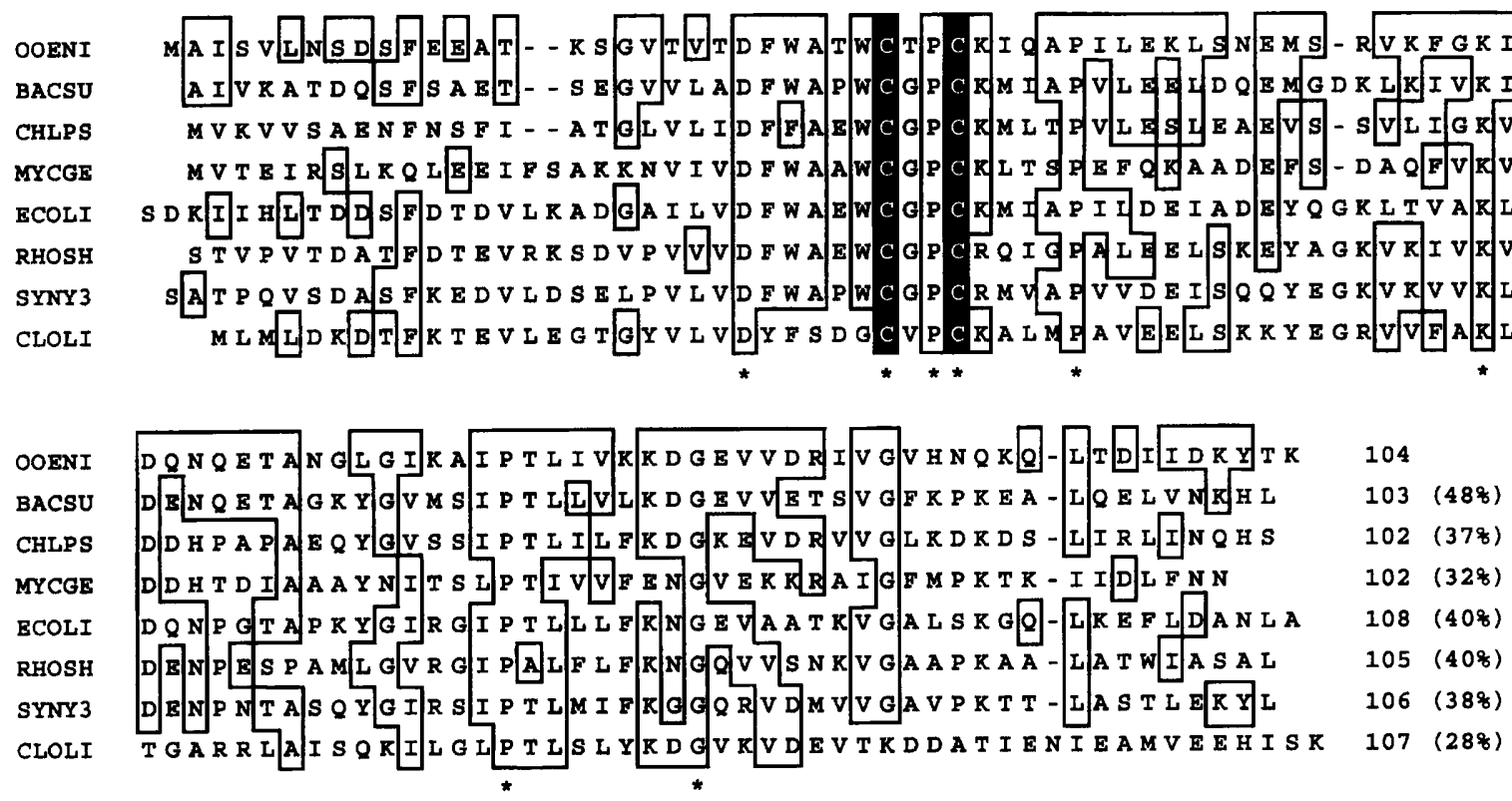

Fig. 2. Comparison of the predicted amino acid sequence of $O$. oeni TrxA (OOENI) with those of TrxA from $B$. subtilis (BACSU) (Chen et al., 1989), Chlamydia psittaci (CHLPS) (Rockey et al., 1996), Mycoplasma genitalium (MYCGE) (Fraser et al., 1995), E. coli (ECOLI) (Lim et al., 1985), R. sphaeroides (RHOSH) (Pille et al., 1990), Synechocystis sp. (SYNY3) (Kaneko et al., 1995) and Clostridium litorale (CLOLI) (Kreimer \& Andreesen, 1995). Amino acids identical to those of O. oeni TrxA are boxed. Asterisks indicate residues that are identical in all sequences. Black boxes indicate redox-active cysteines. Numbers on the right indicate the position of the last amino acid. Percentages in parentheses indicate the identity scores between TrxA from $O$. oeni and from other bacterial species. 


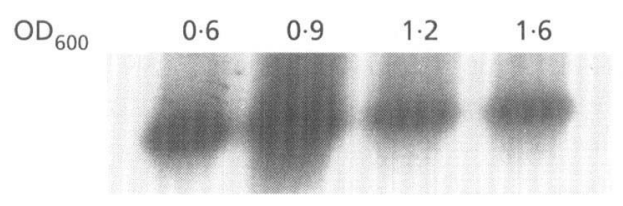

Fig. 3. Detection of trxA mRNA as a function of growth stage. RNA samples were taken from cells during exponential phase $\left(O D_{600} 0.6\right.$ and 0.9$)$, at the beginning of stationary phase $\left(O D_{600}\right.$ $1 \cdot 2)$ and during stationary phase $\left(\mathrm{OD}_{600} 1 \cdot 6\right)$.

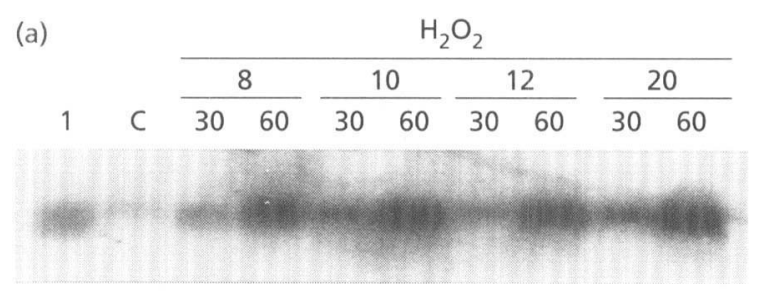

(b)

\begin{tabular}{cccccc} 
& \multicolumn{6}{c}{$4{ }^{\circ} \mathrm{C}$} \\
\cline { 2 - 6 } C & 5 & 10 & 15 & 30 & 60
\end{tabular}

Fig. 4. Northern blot analysis of stress-induced trxA expression. (a) Effect of oxidative stress. RNA samples were isolated from exponentially growing $O$. oeni cells growing in the presence (lane 1) or absence (lane C) of a sublethal dose of hydrogen peroxide $\left(10 \mathrm{mg} \mathrm{l}^{-1}\right)$. In the adjacent lanes, cells in exponential phase were submitted to treatment for 30 or $60 \mathrm{~min}$ with various doses $\left(8,10,12\right.$ and $\left.20 \mathrm{mg}^{-1}\right)$ of hydrogen peroxide, as indicated. (b) Effect of heat shock. RNA samples were isolated from $O$. oeni cells grown at $30^{\circ} \mathrm{C}$ (lane $\mathrm{C}$ ) or from heat-shocked cells at $42^{\circ} \mathrm{C}$. For heat-shocked cells, samples were submitted to a rapid temperature shift (less than $2 \mathrm{~min}$ ). The end of the shift was considered as the start of heat shock, and cells were withdrawn at the time points (in minutes) indicated.

Met $^{-} \operatorname{TrxA}^{-}$and harbouring pGID023 were unable to use methionine sulfoxide to satisfy their methionine requirement. The control strain A312 ( $\mathrm{Met}^{-} \mathrm{TrxA}^{+}$) harbouring pGID023, and both strains BH2012 and A313, carrying the recombinant plasmid pGID608 promoting O. oeni $\operatorname{TrxA}$ synthesis, grew equally well on minimal plates supplemented with L-methionine sulfoxide or L-methionine. This indicated that $O$. oeni thioredoxin serves as a cofactor for $E$. coli methionine sulfoxide reductase in vivo.

\section{Transcription analysis of the trxA gene}

Total RNA was isolated and used to prepare Northern blots from samples taken during exponential phase $\left(\mathrm{OD}_{600} 0.6\right.$ and 0.9$)$, at the beginning of stationary phase $\left(\mathrm{OD}_{600} 1 \cdot 2\right)$ and during stationary phase $\left(\mathrm{OD}_{600} 1 \cdot 6\right)$. These samples were hybridized with the trxA probe which corresponds to the $550 \mathrm{~kb}$ fragment containing part of the trxA gene. Autoradiograms (Fig. 3) showed a single $0.7 \mathrm{~kb}$ transcript hybridizing with the probe. $t r x A$

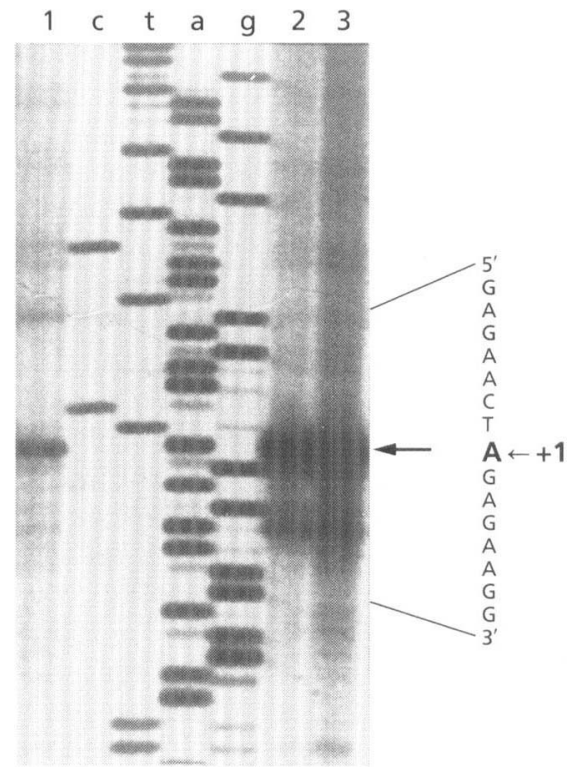

Fig. 5. Mapping of the $5^{\prime}$ end of trxA mRNA by primer extension. Equal amounts of RNA isolated before (lane 1) and $60 \mathrm{~min}$ after (lane 2) the addition of hydrogen peroxide $\left(10 \mathrm{mg} \mathrm{l}^{-1}\right)$, and $15 \mathrm{~min}$ after heat shock (lane 3) were hybridized with primers complementary to the $5^{\prime}$ region of trxA (see Methods). The extension products obtained with primer TRX3 for each RNA sample were electrophoresed in parallel with the sequencing products $(g, a, t$ and $c)$ obtained with the same labelled primer on a sequencing gel. The arrow indicates the position of the deduced start site.

mRNA was detected at a significant level and was estimated to be at roughly the same level during every growth stage, except in late-exponential phase where the transcript appeared at a higher level.

To investigate the effect of oxidative stress, O. oeni cells were cultivated in the presence of a sublethal dose of hydrogen peroxide $\left(10 \mathrm{mg} \mathrm{l}^{-1}\right)$. When the exponential phase was reached, cells were withdrawn and total RNA prepared as described in Methods. Under these growth conditions, a higher level of $\operatorname{tr} x A$ mRNA was detected in comparison to the control (Fig. $4 \mathrm{a}$, compare lanes 1 and C). Moreover, treatment of exponential cells with hydrogen peroxide at various concentrations (8$20 \mathrm{mg} \mathrm{l}^{-1}$ ) for 30 or 60 min significantly enhanced the amount of mRNA detected. The maximum rate of induction was achieved after $60 \mathrm{~min}$ of incubation in the presence of hydrogen peroxide at every concentration tested. No significant increase in the signal was observed at longer incubation times.

In order to examine the effect of temperature increase on $\operatorname{tr} x A$ expression, Northern blot experiments were performed with total RNA extracted from cells submitted to heat shock. The amount of $\operatorname{tr} x A$ messenger was enhanced $5 \mathrm{~min}$ after temperature shift from $30^{\circ} \mathrm{C}$ to $42{ }^{\circ} \mathrm{C}$ and reached a high level of induction after $30 \mathrm{~min}$ of heat shock (Fig. 4b). This temperature induction suggested that the product of $O$. oeni $\operatorname{trx} A$ is a heatshock protein. 
To map the transcription initiation site of the $\operatorname{tr} x A$ gene, nested oligonucleotides TRX1, TRX2 and TRX3 (see Methods) were used in a primer extension assay. RNA samples were extracted from $O$. oeni cells in exponential phase as controls, after addition of hydrogen peroxide (10 $\mathrm{mg} \mathrm{l}^{-1}$ for $\left.60 \mathrm{~min}\right)$ and after heat shock $\left(42{ }^{\circ} \mathrm{C}\right.$ for 15 min). In all culture conditions, a single signal was obtained with oligonucleotides TRX1, TRX2 and TRX3 (Fig. 5), allowing the location of the $5^{\prime}$ end of trxA mRNA 17 nucleotides upstream of the initiation codon. This transcription start point allowed the identification of the promoter for trxA as TTGCAT-17 bpTACAAT. This sequence shows close similarity to the consensus found in the housekeeping promoter of Grampositive bacteria as well as in E. coli (Graves \& Rabinowitz, 1986) and other O. oeni promoters mapped previously (Jobin et al., 1997; Labarre et al., 1996b).

\section{DISCUSSION}

This report presents the DNA sequence, characterization and mRNA analysis of the $\operatorname{trx} A$ gene of $O$. oeni. The primary sequence of the deduced protein revealed that TrxA has significant identity to a number of proteins belonging to the large family of thioredoxins, and in particular to TrxA from B. subtilis ( $48 \%$ identity) (Chen et al., 1989), and that the Cys residues involved in catalysis are conserved. The C-X-X-C motif is critical in determining the exceptional reducing power of disulfide reductase (Konz et al., 1998). Site-directed mutagenesis experiments showed that change of these two central residues can modulate the reducing power of DsbA, a member of the thioredoxin family (Grauschopf et al., 1995). It has recently been reported that thioredoxin from anaerobic, amino-acid-utilizing bacteria possesses a modified consensus sequence at the active centre (Harms et al., 1998). The thioredoxin of such bacteria did not react with thioredoxin reductase of E. coli and the authors suggested that these thioredoxins might form an evolutionarily separate group. One of the two amino acids between the cysteine residues is not conserved in $\mathrm{O}$. oeni $\operatorname{TrxA}$, in which a Thr residue is substituted for the highly conserved Gly residue. This substitution may alter the reducing power of the enzyme. Nevertheless, the protein encoded by the O. oeni trxA gene was able to complement E. coli mutant strains defective in thioredoxin activity. Taken together, these results led us to conclude that the $O$. oeni $\operatorname{tr} x A$ gene encodes a functional thioredoxin.

Few transcriptional analyses of $\operatorname{trx} A$ bacterial genes have been reported so far. The only well-documented example concerns the trxA gene from B. subtilis (Scharf et al., 1998). A variety of stresses, including heat and hydrogen peroxide, strongly enhanced the synthesis of thioredoxin in this bacterium. Transcription initiation of the monocistronic trx $A$ gene occurs at two promoters with different profiles of induction in response to stress. One of these promoters is recognized by the RNA polymerase associated with an alternative $\sigma^{\mathrm{B}}$ factor (Hecker \& Völker, 1998). In Streptomyces coelicolor, the alternative sigma factor $\sigma^{\mathrm{R}}$ modulates expression of the $\operatorname{tr} x B A$ operon, encoding thioredoxin reductase and thioredoxin, in response to oxidative stress (Paget et al. 1998).

The detection of an approximately equal level of $\operatorname{tr} x A$ mRNA in growing cells and during stationary phase suggests that trxA expression is not growth-phase regulated. The level of $\operatorname{tr} x A \mathrm{mRNA}$ is strongly increased by hydrogen peroxide, indicating that thioredoxin is involved in response to oxidative stress, as in many other organisms (Fernando et al., 1992; Kuge \& Jones, 1994; Scharf et al., 1998; Wieles et al., 1997) whereas the E. coli and Salmonella typhimurium trxA genes are not known to be regulated (Farr \& Kogoma, 1991). In addition to oxidative stress, $O$. oeni trx $A$ is also induced by heat shock as is also the case in B. subtilis (Scharf et al., 1998) and in human cells (Jacquier-Sarlin \& Polla, 1996).

The $5^{\prime}$ end of the $\operatorname{tr} x A$ monocistronic transcript was identified in normal growth conditions and allowed us to identify a promoter with a consensus sequence typical for Gram-positive bacteria as well as for E. coli (Graves \& Rabinowitz, 1986). An identical transcription initiation site was obtained with total RNA extracted from cells submitted to oxidative or heat stress. This result suggests that the same potential -35 and -10 regions are recognized by RNA polymerase in all growth conditions tested. During recent work in B. subtilis, at least four different classes of heat-inducible genes were distinguished. The genes of class I are controlled by a repressor which recognizes the CIRCE (controlling inverted repeat of chaperone expression) element (Hecker et al., 1996). Class II genes are positively controlled by the alternative $\sigma^{\mathrm{B}}$ factor (Hecker \& Völker, 1998). Recently, CtsR, a novel regulator of stress and heat shock response, has been shown to act as a repressor of stress genes belonging to class III (Derré $e t$ al., 1999) and those of class IV are regulated by a still unknown mechanism. In lactic acid bacteria, heat-shock genes sharing characteristics of class I (Eaton et al., 1993; Van Asseldonk et al., 1993) and class III (Derré et al., 1999) from B. subtilis have been reported. No CIRCE element was present in the vicinity of the O. oeni $\operatorname{tr} x A$ start site of transcription. To our knowledge, no stress gene expressed under an unusual promoter sequence that may involve an alternative sigma factor has been reported so far in lactic acid bacteria. Moreover, the target consensus sequence corresponding to CtsR was not found in the promoter region of O. oeni trxA. Therefore, the induction of $O$. oeni trx $A$ expression observed after heat or oxidative stresses may require another unknown regulator element, as has been suggested for the heat-shock genes belonging to class IV from B. subtilis.

\section{ACKNOWLEDGEMENTS}

We thank M. Russel and J. Fuchs for providing E. coli strains A312, A313 and BH2012. This work was supported by the Conseil Régional de Bourgogne. 


\section{REFERENCES}

Altschul, S. F., Gish, W., Miller, W., Myers, E. W. \& Lipman, D. J. (1990). Basic local alignment search tool. J Mol Biol 215, 403-410.

Cavin, J. F., Prevost, H., Lin, J., Schmitt, P. \& Diviès, C. (1989). Medium for screening Leuconostoc oenos strains defective in malolactic fermentation. Appl Environ Microbiol 55, 751-753.

Chassy, B. M. \& Murphy, C. M. (1993). Lactococcus and Lactobacillus. In Bacillus subtilis and Other Gram-positive Bacteria: Biochemistry, Physiology, and Molecular Genetics, pp. 65-82. Edited by A. L. Sonenshein, J. A. Hoch \& R. Losick. Washington, DC: American Society for Microbiology.

Chen, N. Y., Zhang, J. J. \& Paulus, H. (1989). Chromosomal location of the Bacillus subtilis aspartokinase II gene and nucleotide sequence of the adjacent genes homologous to $u v r C$ and trx of Escherichia coli. J Gen Microbiol 135, 2931-2940.

D'Enfert, C., Ryter, A. \& Pugsley, A. (1987). Cloning and expression in Escherichia coli of the Klebsiella pneumoniae genes for the production, surface localization and secretion of the lipoprotein pullulanase. $E M B O \mathrm{~J}$ 6, 3531-3538.

Derré, I., Rapoport, G. \& Msadek, T. (1999). CtsR, a novel regulator of stress and heat shock response, controls $c l p$ gene expression in Gram-positive bacteria. Mol Microbiol 31, 117-132.

Dicks, L. M. T., Dellaglio, F. \& Collins, M. D. (1995). Proposal to reclassify Leuconostoc oenos as Oenococcus oeni [corrig.] gen. nov., comb. nov. Int J Syst Bacteriol 45, 395-397.

Eaton, T., Sherman, C. \& Gasson, M. (1993). Cloning and sequence analysis of the dnaK gene region of Lactococcus lactis subsp. lactis. J Gen Microbiol 139, 3253-3264.

Farr, S. B. \& Kogoma, T. (1991). Oxidative stress responses in Escherichia coli and Salmonella typhimurium. Microbiol Rev 55, 561-585.

Fernando, M. R., Nanri, H., Yoshitake, S., Nagato-Kuno, K. \& Minakami, S. (1992). Thioredoxin regenerates proteins inactivated by oxidative stress in endothelial cells. Eur I Biochem 209, 917-922.

Fraser, C. M., Gocayne, J. D., White, O. \& 22 other authors (1995). The minimal gene complement of Mycoplasma genitalium. Science 270, 397-403.

Garmyn, D., Monnet, C., Martineau, B., Guzzo, J., Cavin, J.-F. \& Divies, C. (1996). Cloning and sequencing of the gene encoding $\alpha$ acetolactate decarboxylase from Leuconostoc oenos. FEMS Microbiol Lett 145, 445-450.

Gibson, T. J. (1984). Studies on the Epstein-Barr virus genome. $\mathrm{PhD}$ thesis, University of Cambridge.

Grauschopf, U., Winther, J. R., Korber, P., Zander, T., Dallinger, P. \& Bardwell, J.C.A. (1995). Why is DsbA such an oxidizing disulfide catalyst? Cell $\mathbf{8 3}, \mathbf{9 4 7 - 9 5 5 . ~}$

Graves, M. C. \& Rabinowitz, J. C. (1986). In vivo and in vitro transcription of the Clostridium pasteurianum ferredoxin gene. I Biol Chem 261, 11409-11415.

Guzzo, J., Delmas, F., Pierre, F., Jobin, M.-P., Samyn, B., Van Beeumen, J., Cavin, J.-F. \& Diviès, C. (1997). A small heat shock protein from Leuconostoc oenos induced by multiple stresses and during stationary growth phase. Lett Appl Microbiol 24, 393-396.

Guzzo, J., Jobin, M.-P. \& Diviès, C. (1998). Increase of sulfite tolerance in Oenococcus oeni by means of acidic adaptation. FEMS Microbiol Lett 160, 43-47.

Harms, C., Meyer, M. A. \& Andreesen, J. R. (1998). Fast purification of thioredoxin reductase and of thioredoxins with an unsual redox-active centre from anaerobic, amino-acid-utilizing bacteria. Microbiology 144, 793-800.
Hecker, M. \& Völker, U. (1998). Non-specific, general and multiple stress resistance of growth-restricted Bacillus subtilis cells by the expression of the sigma B regulon. Mol Microbiol 29, 1129-1136. Hecker, M., Schumann, W. \& Völker, U. (1996). Heat-shock and general stress response in Bacillus subtilis. Mol Microbiol 19, $417-428$.

Higgins, D., Thompson, J., Gibson, T., Thompson, J. D., Higgins, D. G. \& Gibson, J. J. (1994). CLUSTAL w : improving the sensibility of progressive multiple sequence alignment through sequence weighting, positive-specific gap penalties and weight matrix choice. Nucleic Acids Res 22, 4673-4680.

Holmgren, A. (1985). Thioredoxin. Annu Rev Biochem 54, 237-271.

Holmgren, A. (1989). Thioredoxin and glutaredoxin systems. J Biol Chem 264, 13963-13966.

Holmgren, A., Ohlsson, I. \& Grakvist, M.-L. (1978). The thioredoxin from Escherichia coli. Radioimmunological and enzymatic determinations in wild type cells and mutants defective in phage T7 DNA replication. J Biol Chem 253, 430-436.

Hols, P., Ferain, T., Garmyn, D., Bernard, N. \& Delcour, J. (1994). Use of homologous expression-secretion signals and vector-free stable chromosomal integration in engineering of Lactobacillus plantarum for $\alpha$-amylase and levanase expression. Appl Environ Microbiol 60, 1401-1413.

Jacquier-Sarlin, M. R. \& Polla, B. S. (1996). Dual regulation of heat-shock transcription factor (HSF) activation and DNAbinding activity by $\mathrm{H}_{2} \mathrm{O}_{2}$ : role of thioredoxin. Biochem $J 318$, 187-193.

Jobin, M.-P., Delmas, F., Garmyn, D., Diviès, C. \& Guzzo, J. (1997). Molecular characterization of the gene encoding an 18-kilodalton small heat shock protein associated with the membrane of Leuconostoc oenos. Appl Environ Microbiol 63, 609-614.

Kaneko, T., Tanaka, A., Sato, S., Kotani, H., Sazuka, T., Miyajima, N., Sugiura, M. \& Tabata, S. (1995). Sequence analysis of the genome of the unicellular cyanobacterium Synechocystis sp. strain PCC6803. I. Sequence features in the $1 \mathrm{Mb}$ region from map positions $64 \%$ to $92 \%$ of the genome. DNA Res $2,153-166$

Konz, J. O., King, J. \& Cooney, C. L. (1998). Effects of oxygen on recombinant protein expression. Biotechnol Prog 14, 393-409.

Kreimer, S. \& Andreesen, J. R. (1995). Glycine reductase of Clostridium litorale. Cloning, sequencing, and molecular analysis of the $\operatorname{grdAB}$ operon that contains two in-frame TGA codons for selenium incorporation. Eur J Biochem 234, 192-199.

Kuge, S. \& Jones, N. (1994). YAP1 dependent activation of TRX2 is essential for the response of Saccharomyces cerevisiae to oxidative stress by hydroperoxides. EMBO J 13, 655-664.

Kunkee, R. E. (1967). Malolactic fermentation. Adv Appl Microbiol 9, 235-279.

Labarre, C., Guzzo, J., Cavin, J. F. \& Diviès, C. (1996a). Cloning and characterization of the genes encoding the malolactic enzyme and the malate permease of Leuconostoc oenos. Appl Environ Microbiol 62, 1274-1282.

Labarre, C., Diviès, C. \& Guzzo, J. (1996b). Genetic organization of the mle locus and identification of a mleR-like gene from Leuconostoc oenos. Appl Environ Microbiol 62, 4493-4498.

Lim, C. J., Geraghty, D. \& Fuchs, J. A. (1985). Cloning and nucleotide sequence of the trxA gene of Escherichia coli $\mathrm{K}-12 . J$ Bacteriol 163, 311-316.

Moore, E. C., Reichard, P. \& Thelander, L. (1964). Enzymatic synthesis of deoxynucleotides. V. Purification and properties of thioredoxin reductase from Escherichia coli B. J Biol Chem 239, 3445-3453. 
Navarro, F. \& Florencio, F. J. (1996). The cyanobacterial thioredoxin gene is required for photoautotrophic and heterotrophic growth. Plant Physiol 11, 1067-1075.

Paget, M. S., Kang, J. G., Roe, J. H. \& Buttner, M. J. (1998). SigmaR, an RNA polymerase sigma factor that modulates expression of the thioredoxin system in response to oxidative stress in Streptomyces coelicolor A3(2). EMBO J 17, 5776-5782.

Pasternak, C., Assemat, K., Clement-Metral, J. D. \& Klug, G. (1997). Thioredoxin is essential for Rbodobacter sphaeroides growth by aerobic and anaerobic respiration. Microbiology 143, 83-91.

Pille, S., Chuat, J. C., Breton, A. M., Clement-Metral, J. D. \& Galibert, F. (1990). Cloning, nucleotide sequence, and expression of the Rhodobacter sphaeroides Y thioredoxin gene. J Bacteriol 172, 1556-1561.

Rockey, D. D., Chesebro, B. B., Heinzen, R. A. \& Hackstadt, T. (1996). A $28 \mathrm{kDa}$ major immunogen of Chlamydia psittaci shares identity with Mip proteins of Legionella spp. and Chlamydia trachomatis - cloning and characterization of the C. psittaci miplike gene. Microbiology 142, 945-953.

Russel, M. \& Model, P. (1986). The role of thioredoxin in filamentous phage assembly. Construction, isolation, and characterization of mutant thioredoxins. J Biol Chem 261, 14997-15005.

Sambrook, J., Fritsch, E. F. \& Maniatis, T. (1989). Molecular
Cloning: a Laboratory Manual, 2nd edn. Cold Spring Harbor, NY: Cold Spring Harbor Laboratory.

Sanger, F., Nicklen, S. \& Coulson, A. R. (1977). DNA sequencing with chain-terminating inhibitors. Proc Natl Acad Sci USA 74, 5463-5467.

Scharf, C., Riethdorf, S., Ernst, H., Engelmann, S., Völker, U. \& Hecker, M. (1998). Thioredoxin is an essential protein induced by multiple stresses in Bacillus subtilis. J Bacteriol 180, 1869-1877.

Van Asseldonk, M., Simons, A., Visser, H., De Vos, W. M. \& Simons, G. (1993). Cloning, nucleotide sequence, and regulatory analysis of the Lactococcus lactis dnaJ gene. J Bacteriol 175, 1637-1644.

Wieles, B., Ottenhoff, T. H. M., Steenwijk, T. M., Franken, K., Devries, R. R. P. \& Langermans, J. A. M. (1997). Increased intracellular survival of Mycobacterium smegmatis containing the Mycobacterium leprae thioredoxin-thioredoxin reductase gene. Infect Immun 65, 2537-2541.

Yang, D. \& Woese, C. R. (1989). Phylogenetic structure of the Leuconostoc: an interesting case of rapidly evolving organism. Syst Appl Microbiol 12, 145-149.

Received 20 November 1998; revised 18 January 1999; accepted 21 January 1999. 